\title{
The Role of Motivation, Work Discipline and Training in Improving Employee Performance
}

\author{
Tri Ariprabowo ${ }^{1}$ \\ Dini Marita Sari ${ }^{2}$ \\ Sukaris $^{2}$ \\ ${ }^{1}$ Management Study Program, Faculty of Economics, Universitas PGRI Adi Buana Surabaya, \\ East Java, Indonesia \\ tri_ariprabowo@unipasby.ac.id \\ ${ }^{2}$ Management Study Program, Faculty of Economics and Business \\ Universitas Muhammadiyah Gresik, East Java, Indonesia \\ sukaris21@umg.ac.id
}

\begin{abstract}
ABSTRAK
Penelitian ini bertujuan untuk melakukan pengujian Pengaruh Motivasi, Disiplin Kerja Serta Motivasi Terhadap Kinerja Karyawan. Jumlah sampel dalam penelitian ini 89 orang karyawan operasional Di PT. PembangkitanJawa-Bali UP Gresik, Menggunakan metode teknik Probability Sampling jenis Random Sampling. Pengumpulan data pada penelitian ini adalah menggunakan kuesioner dan wawancara. Teknik analisis data yang digunakan adalah analisis regresi linier berganda. Hasil penelitian ini menyimpulkan bahwa hasil pengujian secara simultan Motivasi, Disiplin Kerja Serta Motivasi berpengaruh signifikan terhadap kinerja. Hasil pengujian secara parsial Motivasi berpengaruh dan signifikan terhadap kinerja, disiplin kerja juga berpengaruh dan signifikan terhadap kinerja dan motivasi juga berpengaruh dan signifikan terhadap.
\end{abstract}

Kata Kunci: Motivasi, Disiplin Kerja, Pelatihan, Kinerja

\begin{abstract}
This study aims to test the effect of motivation, work discipline and motivation on employee performance. The number of samples in this study were 89 operational employees at PT. Generation of Java-Bali UP Gresik, using the technique method Probability Sampling of Random Sampling type. Data collection in this study was using questionnaires and interviews. The data analysis technique used is multiple linear regression analysis. The results of this study conclude that the results of simultaneous testing of motivation, work discipline and training have a significant effect on performance. Partial test results Motivation has an effect and is significant on performance, work discipline also has an effect and is significant on performance and training also has an effect and is significant on performance
\end{abstract}

Key words: Motivation, Work Discipline, Training, Performance

\section{INTRODUCTION}

Human Resources (HR) is the company's most expensive asset compared to other assets because HR is the main driver of the company's organization. HR must be managed optimally, continue and be given extra attention and fulfill their rights, besides that $\mathrm{HR}$ is a partner of entrepreneurs to achieve organizational goals. Thus, human resources must always improve their competence, along with the development of the era of globalization.
In order to compete in business competition, companies are required to acquire, develop, and maintain quality Human Resources. With the increase in the quality of Human Resources, it is expected that employees can work productively and professionally so that the performance they achieve is expected to be more satisfactory according to the required work standards. 
According to Mangkunegara (2013; 67) performance is the result of work in quality and quantity achieved by an employee in carrying out his duties in accordance with the responsibilities given to him. Meanwhile, according to Hasibuan (2011: 94) performance is a work achieved by a person in carrying out the tasks assigned to him based on skills, experience and sincerity and time.

The company's performance is said to be of high quality and successful in achieving its goals can be influenced by factors originating from within the company such as work discipline, employee training in accordance with the employee's ability to complete their duties and responsibilities, so as to produce quality output. This statement is reinforced by Sedarmayanti (2011) in (Jacob, et al. 2014).

Training is part of an educational process, the aim of which is to improve the special abilities or skills of a person or group of people. According to Marlia $(2007 ; 72)$ the implementation of the training is directed at increasing skills, knowledge and changing attitudes or work behavior of employees, through the learning process applied to the training, it is hoped that there will be changes in participants, namely from not knowing to knowing and being less skilled to being skilled and from negative behavior. positive behavior and so on.

Sofyandi (2008:113) explains that training is a program that is expected to provide a stimulus or stimulus to someone to be able to improve abilities in certain jobs and gain general knowledge and understanding of the overall work environment and organization.

Training is part of education that involves the learning process to acquire and improve skills outside the education system that applies in a relatively short time with methods that prioritize practice rather than theory (Rivai and Sagala, 2013; 211).

Employees at PT. The Java-Bali power plant of UP Gresik must have competence in accordance with the field it occupies. When there is a gap between the competency requirements in accordance with the field and the competencies it has, then one way out to overcome it is through training. Based on the results of observations and data on employee performance achievements, it is indicated that there are still training that have not been followed in full from the amount that should have been, and the responsibilities of employees have not been carried out properly.

According to Hasibuan $(2011 ; 193)$ states that the better the employee discipline, the higher the work performance that can be achieved. Discipline is a person's willingness and willingness to obey and obey the norms of the regulations that apply around him, and good employee discipline will accelerate the achievement of company goals, while declining discipline will become a barrier and slow down the achievement of company goals.

PT. The Java-Bali Generation UP Gresik has implemented strict discipline, which can be seen in the use of a computerized attendance system using system finger scan.system Finger scan as a facility to manage, monitor and produce leave and attendance reports that can be used, to see employee absenteeism behavior and see employee performance. The computerization of the absent recapitulation system takes place in the attendance section.

Meanwhile, according to Hasibuan (2011: 143) motivation is the provision of a driving force that creates a person's work enthusiasm so that they want to work together, work effectively, and are integrated with all their efforts to achieve satisfaction. The encouragement will arise if someone has a need to fulfill, for example the need to achieve success, the need to be able to socialize with other employees and the need to gain power.

Not all employees feel motivated just because of material things, in addition to money and goods, giving attention from superiors to subordinates and rewards for employees who excel will affect the level of employee motivation. This can be an encouragement so that employees can work better and can 
improve performance and have a sense of responsibility for their work.

The discrepancy between the level of education and the position, duties and responsibilities of employees is suspected to be the cause of the low motivation of employees to be able to have an influence on other employees. The problem that arises from this is that employees do not know clearly what their duties and responsibilities should be so that employees are not compelled to take advantage of the time given by the agency to work as time to improve work abilities.

Based on the description of the background above, the formulation of the problem is the Effect of Motivation, Work Discipline and Training on Employee Performance.

\section{LITERATURE REVIEW}

\section{Motivation}

Siagian (2009:102) Motivation is the driving force for someone to contribute as much as possible for the success of the organization to achieve its goals.

Hasibuan (2011:143) Work motivation is the provision of a driving force that creates one's work enthusiasm so that they want to work together, work effectively, and be integrated with all their efforts to achieve satisfaction.

McClelland, in Mangkunegara (2011: 94) Motivation is a mental condition that encourages a person to achieve maximum performance.

With the understanding above, it can be concluded that motivation is the impetus for someone to have the desire to do things that cause, channel and support human behavior so that they want to work hard to achieve the expected goals.

Zainudin (2014) quoted by Manullang, $(2003 ; 151)$ in the factors that influence employee motivation and satisfy and encourage people to work well consisting of: Achievement, Recognition, Work itself, Responsibility and Progress.

\section{Work Discipline}

Hasibuan $(2011 ; 193)$ defines discipline as a person's awareness and willingness to obey all company regulations and applicable social norms. According to Sutrisno $(2014 ; 87)$ that discipline is an attitude of willingness and willingness of a person to obey and obey the norms of the regulations that apply around him.

According to Sutrisno $(2014 ; 86)$ discipline is an attitude of willingness and willingness of a person to obey and obey the norms of the regulations that apply around him. Good employee discipline will accelerate the company's goals, while declining discipline will become a barrier and slow down the achievement of company goals.

Fitriana and Agustina (2012) concluded that discipline is the attitude of employees to comply with the rules set by the organization or agency. Discipline is the willingness of employees to obey the rules and norms that apply within the company, both written rules and unwritten rules. written (Permatasari, et al. 2015).

\section{Training}

Sutrisno $(2014 ; 66)$ explains that training is related to planned efforts that are carried out in order to achieve mastery of skills, knowledge, and attitudes that are relevant to work. Training is a short-term educational process using systematic and organized procedures, so that operational employees learn knowledge of working techniques and skills for specific purposes. Andrew F. Sikula in Hasibuan (2011: 70).

Sofyandi (2008:113) explains that training is a program that is expected to provide a stimulus or stimulus to someone to be able to improve abilities in certain jobs and gain general knowledge and understanding of the overall work environment and organization. Training is part of education that involves the learning process to acquire and improve skills outside the education system that applies in a relatively short time with methods that 
prioritize practice rather than theory (Rivai and Sagala, 2013; 211).

According to Notoatmodjo $(2009 ; 23)$ evaluation of training includes:

1. Evaluation of the process, which includes:

a. Organization of training implementation, for example: administration, consumption, room, staff and so on.

b. Delivery of training materials, for example: relevance, depth, teaching and so on.

2. Evaluation of the results, which includes an evaluation of the extent to which the material provided can be mastered or absorbed by the training participants. Furthermore, whether there is an increase in the ability or skills, knowledge, attitudes of the trainees.

\section{Performance}

Performance is a real behavior that is displayed by everyone as work performance produced by employees according to their role in the company (Rivai and Sagala, 2013; 548). According to Bangun (2012; 231) that performance (performance) is the result of work achieved by a person based on job requirements (job requirements).

Sukaris et al., (2020), Performance is a result that has been achieved or exceeded the standards that employees do in their work based on what has been determined.

Bernardin and Russell in Sutrisno (2014; 149) performance is a record of the results obtained from certain job functions or certain activities over a certain period of time. Performance is a real behavior that is displayed by everyone as work performance produced by employees in accordance with their role in Rivai's company $(2013 ; 548)$.

\section{The relationship between motivation and performance}

One thing that needs to be done to improve the performance of employees is that employees need good motivation so that in carrying out every task and job they are given they can work with high self-confidence accompanied by high morale as well. The more they are motivated it will make their totality in work increase and will have a positive impact on improving the performance they will achieve at PT. Java-Bali Generation UP Gresik.

To reveal the relationship between work motivation and employee performance, according to Mangkunegara (2011:122) stated the relationship between motivation and performance, namely, "That an employee will be willing to make greater efforts if it is believed that the effort will result in a good performance appraisal and Good performance will result in greater rewards from the organization, such as bigger bonuses, salary increases, and promotions and all of them are related to the possibility of achieving personal goals.

\section{The Relationship of Work Discipline to Performance}

The application of discipline is expected that employees will have behavior that always obeys all regulations. The better the employee discipline, the higher the performance that can be achieved (Hasibuan, 2011; 193).

Furthermore, to examine and to determine the relationship between discipline and performance, the researchers used references from the results of research conducted by others, including research conducted by Wiratama and Sintaasih (2013), Yakub et al. (2014), Permatasari, et al. (2015), found that discipline has a significant effect on performance.

\section{The Relationship of Training to Performance}

According to Rivai (2005), training is an activity to improve current performance and future performance. Training is one of the most important factors in achieving agency goals. In the implementation of training, employees are expected to have competencies indicated by the attitude and ability to carry out their duties. Employee productivity increases, meaning the 
organization concerned will benefit

Notoatmodjo (2009: 18).

\section{Hypothesis}

1. It is suspected that there is an influence of motivation on the performance of Operational Employees of PT. Java-Bali Generation UP Gresik.

2. It is suspected that there is an influence of work discipline on the performance of Operational Employees of PT. Java-Bali Generation UP Gresik.

3. It is suspected that there is an effect of training on the performance of Operational Employees of PT. Java-Bali Generation UP Gresik.

4. It is suspected that there is an influence of Discipline, Motivation and Training on the performance of Operational Employees of PT. Java-Bali Generation UP Gresik.

\section{METHODS}

The approach used in this research is quantitative. According to Arikunto (2013: 203) The research method is the method used by researchers in collecting research data. In obtaining the data and information needed to discuss the problem, the object of this research was conducted at PT. Java Bali Generation UP Gresik as a research site located on Jalan Harun Tohir 1 Gresik, East Java. In accordance with this opinion, the population used by the researcher is the operator employee at PT. Java Bali Generation UP Gresik totaling 184 people. In this study, sampling using the technique of the Probability Sampling type of Simple Random Sampling which is a sampling technique carried out randomly without regard to the existing strata in the population. The type of data used is primary data and the source of the data obtained in this study comes from the human resources department at PT. Java-Bali Generation UP Gresik. Data collection techniques using a questionnaire.

The variables in this study consisted of the independent variable (Independent Variable) with the symbol $\mathrm{X}$ Motivation ), Work Discipline (), Training () and the Bound Variable or (Dependent Variable) with the symbol $\mathrm{Y}$ is the Employee Performance Performance Operator PT. Java-Bali power plant.

\section{RESULTS AND DISCUSSION Validity Test}

This study used a questionnaire to collect research data. A questionnaire is said to be valid if the statement on the questionnaire is able to reveal something that will be measured by the questionnaire. In the content validity test, a statement or variable is declared valid if rcount is greater than rtable. From the results of the instrument validity test, all variables obtained $\mathrm{r}$ count $>\mathrm{r}$ table 0.188 . So all the statement items from the independent and dependent variables are proven valid.

\section{Reliability Test}

Reliability is said to be reliable if it has avalue Cronbach Alpha > 0.70 (Nunnally in Ghozali, 2013 ; 48). that each variable the value Cronbach Alpha is greater than 0.70. Thus it can be concluded that the measuring instrument used in this study is reliable.

\section{Classical Assumption Test}

The multicollinearity test in this study uses the basis for decision making, if the Variance Inflation Factor (VIF) value is not more than 10 and the Tolerance (TOL) value is not less than 0.1 , then the model can be said to be free from multicollinearity (Ghozali, 2013 ;106). From the results of data management, the tolerance value is smaller than 10 and the VIF is greater than 0.1 , so it can be concluded that the regression model does not have multicollinearity problems. Detection of heteroscedasticity is tested through a scatter plot chart on the basis of analysis, if the points contained in the charts form an orderly pattern of dots like waves, widen and then narrow, it means that heteroscedasticity occurs. If there is no clear pattern, such as the dots spread above 
and below the number 0 on the $\mathrm{Y}$ axis, then there is no heteroscedasticity (Ghozali $2013 ; 139)$. the distribution of research data in a scatterplot spreads randomly and does not form a certain pattern. Thus it can be concluded that the regression model is free of heteroscedasticity. The normality test in this study using a graph is detected by looking at the spread of data (points) on the diagonal axis of the graph or histogram of the residuals. The basis for decision making according to Ghozali (2013; 163) are; 1) If the data spreads around the diagonal line and follows the direction of the histogram line showing a normal distribution pattern, then the regression model meets the assumption of normality; 2) If the data spreads far from the diagonal and does not follow the direction of the histogram line, it does not show a normal distribution pattern, then the regression model does not meet the assumption of normality.Graph Normal PP Plot of Regression Standardized Residual describes the spread of data around the diagonal line and its distribution follows the direction of the graph's diagonal line, so the regression model used in this study meets the assumption of normality.

\section{The results of the Partial Coefficient Test}

Analysis (t-test) for The Motivation variable obtained the t-value count of 3.564 while the t-table of 1.988. These results indicate that $t$ count $>t$ table with a significance of $5 \%$. Thus the results of statistical calculations show that partially the motivation variable is proven to have a significant effect on the Operational Employee Performance of PT. Java-Bali Generation UP Gresik.

The work discipline variable obtained tcount value of 2.067 while t-table of 1.988 . These results indicate that $t$ count $>t$ table with a significance of 5\%. Thus the results of statistical calculations show that partially the Work Discipline variable has a significant effect on the Employee Performance of PT. Java-Bali generation UP Gresik training variable obtained t value of 3.122 while $t$ table of 1.988. These results indicate that $\mathrm{t}$ count $>\mathrm{t}$ table with a significance of $5 \%$. Thus the results of statistical calculations show that partially the training variable has a significant effect on employee performance at PT. Java-Bali Generation UP Gresik

\section{Discussion}

Based on the research and analysis that the researchers processed using SPSS 22 for windows , the researchers could interpret the results as follows:

1. Proof of the partial regression hypothesis ( $t$ test) is shown to determine the effect of each independent variable consisting of Motivation, Work Discipline and Training partially on the dependent variable, namely Employee Performance.

a. Motivation obtained $t$ count of $(3,564)$, while $t$ table of $(1,988)$ at a significant level of $5 \%$, thus the results of statistical calculations show that partially the variable Motivation () has been shown to have a significant effect on the Operational Employee Performance of PT. Java-Bali Generation UP Gresik. Hasibuan (2011; 141) concludes that work motivation causes, distributes, and supports human behavior, so that they want to work hard and enthusiastically achieve optimal results on employee performance at Operational Employees at PT. The Java-Bali UP Gresik power plant has been proven to be true.

b. Work Discipline obtained $t$ count of $(2,067)$, while the $t$ table of $(1,988)$ at a significant level of $5 \%$. Based on these results, work discipline affects the performance of Operational employees of PT. Java-Bali Generation UP Gresik. So that research according to Cahyo Laksono (2015) concluded that showing a strong relationship between work discipline, work placement and work motivation on the performance of 
Operational Employees of PT. The Java-Bali UP Gresik power plant has been proven to be true.

c. Training obtained t count of (3.122), while the $t$ table of $(1.988)$ at a significant level of 5\%. Based on these results, work discipline affects the performance of Operational employees of PT. Java-Bali Generation UP Gresik. So that research according to Elfina Marlia (2007) concluded that it shows a strong relationship between education and training on employee performance, and has a positive effect, and according to Notoatmodjo's theory (2009: 18) states that by increasing the abilities or skills of employees, increasing work productivity of employees .

2. The results of simultaneous hypothesis testing using the $\mathrm{F}$ test, the regression value obtained has a significance level of 0.000 this value is smaller than 0.05 or a significance value $<$ and $\mathrm{F}$ count has a value of 10.910 while $F$ table has a value of 3.104 this means F count > F table, so that Ho is rejected and Ha is accepted, meaning that it is simultaneously proven that there is a significant effect of Motivation, Work Discipline, and Training on the Operational Employee Performance of PT. Java-Bali Generation UP Gresik.

\section{CONCLUSIONS}

Based on the results of data processing in this study, it can be concluded that Motivation has a significant effect on Operational Employee Performance at PT. Generation of Java-Bali UP Gresik, work discipline has a significant effect on the Performance of Operational Employees at PT. Java-Bali Generation UP Gresik. Training has a significant effect on the Performance of Operational Employees at PT. Java-Bali Generation UP Gresik. The results of hypothesis testing through the $\mathrm{F}$ test (simultaneous) state that the variables of Training and Work Discipline simultaneously have a significant effect on Operational Employee Performance at PT. Generation JavaBali UP Gresik. Based on the analysis, discussion, and conclusions of the study, the managerial aspects and recommendations for the future researchers is the first For Managerial Aspects, In the motivation variable has the highest constant value of 0.395 on the indicator of encouraging encouragement, achieving company goals, encouraging encouragement, must pay more attention to employees by providing motivation to work harder so that it can make it easier to achieve company goals, the work discipline variable has a constant value of 0.218 at indicators of compliance with company regulations regarding behavior at work must be more assertive so that employees comply with applicable regulations in the company the training variable has a constant value of 0.364 on the material delivery indicator, should be able to prepare its employees with the provision of training to be carried out and supervise when the training is carried out so that the employees who follow get the material optimally. Second, for further researchers, the results of this study can be used as a reference for future researchers by increasing the number of variables and using different analytical techniques.

\section{REFERENCES}

Arikunto, Suharsini, (2010), Prosedur Penelitian Suatu Pendekatan Praktek, Edisi Kelima, Rineka Cipta Jakarta.

Bangun, Wilson, (2012), Manajemen Sumber Daya Manusia, Erlangga, Jakarta.

Ghozali, Imam, (2013), Aplikasi Analis Multivariate Dengan Program IBM SPSS 21, Edisi 2, Universitas Diponegoro, Semarang.

Hasibuan, Malayu S.P., (2011), Manajemen Sumber Daya Manusia Edisi Revisi, Cetakan Kelima Belas, Bumi Aksara, Jakarta.

Mangkunegara, Anwar Prabu, (2011), Manajemen Sumber Daya manusia Perusahaan, PT. Remaja Rosdakarya. 
Marlia, Elfina, (2007), Pengaruh Pendidikan dan Pelatihan Terhadap Kinerja Karyawan Di PT. Inti (Persero) Bandung, Skripsi, Bandung : Program Studi Manajemen Pada Fakultas Bisnis dan Manajemen, Universitas Widyatama.

Notoatmodjo, Soekidjo, (2009), Pengembangan Sumber Daya Manusia, Rineka Cipta, Jakarta.

Nurmasari, Detri Karya dan Arif Rifai, (2012), Pengaruh Pendidikan dan Pelatihan Terhadap Peningkatan Kinerja Pada Badan Kepegawaian Daerah Kabupaten Bengkalis, Jurnal RAT, Vol. 1 No. 2, Desember, hal 168-184.

Permatasari, Jundah Ayu, Mochammad AL Musadieq dan Yuniadi Mayoman, (2015), Pengaruh Disiplin Kerja Dan Motivasi Kerja Terhadap Prestasi Kerja Karyawan, Jurnal Administrasi Bisnis, Vol. 25 No. 1, Agustus, hal 1-9.

Pratiwi, Anisa, (2014), Pengaruh Motivasi dan Disiplin Kerja Terhadap Kinerja Pegawai PT. Telekomunikasi Indonesia, Tbk Wilayah Telkom Pekalongan. Skripsi. Ponegoro : Program Sarjana Ekonomika dan Bisnis, Universitas Diponegoro.

Rapareni Yussi, (2013), Pengaruh Pendidikan dan Pelatihan Terhadap Produktivitas Guru Yayasan Jihadiyah Palembang, Jurnal Ekonomi dan Informasi Akuntansi, Vol. 3 No. 3, September, hal 216-229

Rivai, Veithzal dan Ella Jauvani Sagala, (2013), Manajemen Sumber Daya Manusia Untuk Perusahan Dari Teori Ke Praktik, Cetakan Ke-5, PT Rajagrafindo Persada.

Sasra, Rizaldo Yan, Abdul Rahman Lubis dan Syafruddin Chan, (2015), Pengaruh Kompetensi Pendidikan Dan Pelatihan Serta Penempatan Pegawai Terhadap Pengembangan karir Dan Dampaknya Terhadap Kinerja Pegawai Sekretariat Daerah Provinsi Aceh, Jurnal Manajemen Pasca sarjana Universitas Syiah Kuala, Vol. 4 No. 2, Mei, pp. 237247.
Sedarmayanti, (2009), Sumber Daya Manusia dan Produktivitas Kerja, cetakan ke-3 CV Mandar Maju, Bandung.

Simamora, Henry. (2007), Manajemen Sumber Daya Manusia, edisi kedua, Yogyakarta :YKPN Jakarta.

Sofyandi, Herman, (2008), Manajemen Sumber Daya Manusia, Edisi Pertama, Graha Ilmu, Yogyakarta.

Sugiyono, (2013), Metode Penelitian Kuantitatif, Kualitatif, Dan $R \& B$, Cetakan Ke-19, Alfabeta, Bandung.

Sukaris, S., Prathiwi, M. P., \& Pristyadi, B. (2020). Meningkatkan Kinerja Karyawan Melalui Keterikatan, Budaya Organisasi, Dan Gaya Kepemimpinan. Equilibrium: Jurnal Ekonomi-Manajemen-Akuntansi, 16(1), 15-21

Sutrisno, Edi, (2014), Manajemen Sumber Daya Manusia, Cetakan Ke-6, Kencana Prenada Media Grup, Jakarta.

Wiratama dan Sintaasih, (2013), Pengaruh Kepemimpinan, Diklat, Dan Disiplin Kerja Terhadap Kinerja Karyawan PDAM Tirta Mangutama Kabupaten Badung, Jurnal Manajemen, Strategi Bisnis dan Kewirausahaan. Vol. 7 N0. 2, Agustus, hal 126-134.

Yakub, Suardi, Anton Tulim, Suharsil, (2014), Pengaruh Disiplin Kerja, Pendidikan Dan Pelatihan Terhadap Kinerja Pegawai Pada PT Kertas Kraft Aceh (PERSERO), Jurnal SAINTIKOM, Vol 13 No. 3, September, hal 227-238. 